\title{
Further Reading
}

\author{
A brief selection of related books
}

(Books which may require some mathematical background are preceded by an asterisk)

Albert, David (1992). Quantum mechanics and experience. Harvard University Press

*Albert, David and Ney, Alyssa , editors (2013). The wave function: Essays on the metaphysics of quantum mechanics. Oxford University Press

Baggot, Jim (1992). The meaning of quantum theory. Oxford University Press

Barbour, Brian (1999). The end of time. London. Weidenfeld \& Nicolson

Barrow, John (1991). Theories of everything. Oxford. Clarendon Press

Barrow, John (1994). The origin of the universe. Weidenfeld \& Nicolson

Barrow, John, \& Tipler, Frank, \& Wheeler, John (1986). The anthropic cosmological principle. Oxford University Press

Barrow, John (2002). The constants of nature: The numbers that encode the deepest secrets of the universe. Jonathan Cape, Random House

Barrow, John (2012). The book of universes: Exploring the limits of the cosmos. London. The Bodley Head, Random House

Barrow, John (2000). The book of nothing: Vacuums, voids, and the latest ideas about the origins of the universe. Jonathan Cape, Random House

Bell, John (1987). Speakable and unspeakable in quantum mechanics. Cambridge University Press

Bojowald, Martin (2009). Zurück vor den Urknall: Die ganze Geschichte des Universums. Berlin. Fischer Verlag

Boslough, John (1992). Masters of time. London. J.M. Dent

Brockman, John editor (2014). The Universe. Harper Perennial

Bruce, Colin (2004). Schrödinger's rabbits. Joseph Henry Press

* Carr, Bernard editor (2007). Universe or multiverse? Cambridge University Press

Chown, Marcus (1993). Afterglow of creation. Arrow Books

Chown, Marcus (2002). The universe next door. Headline Book Publishing

*Cohen Tannoudji (1977). Quantum mechanics 1\&2. Paris. Hermann

*Cohen, Paul J. (2008). Set theory and the continuum hypothesis. Dover Publications

Darling, David (1996). Zen physics. Harper \& Collins

Darling, David (1993). Equations of eternity. Hyperion Books

Davies, Paul (1995). About time. Viking Books

Davies, Paul (1992). The mind of God. Simon \& Schuster

Davies, Paul (1984). Superforce. William Heinemann

Davies, Paul (1982). The edge of infinity. Touchstone Books, Simon \& Schuster

Davies, Paul (2006). The Goldilocks enigma. Allen Lane, Penguin Books

d'Espagnat, Bernard (2002). Traité de physique et de philosophie. Paris. Fayard

d'Espagnat, Bernard (1985). Une incertaine réalité. Paris. Gauthiers-Villars

d'Espagnat, Bernard (1981). A la recherche du réel. Paris. Gauthiers-Villars

Deutsch, David (1997). The fabric of reality. Allen Lane, Penguin Books

Devlin, Keith (2002). The millennium problems. Basic Books

Eagleman, David (2011). Incognito: The secret lives of the brain. Pantheon Books

*Earman, John (1995). Bangs, crunches, whimpers, and shrieks: Singularities and acausalities in relativistic space-times. Oxford University Press

Earman, John (1989). World enough and space time. Cambridge MA. MIT Press 
*Everett, Hugh, with contributions by DeWitt, Bryce (1973). The many worlds interpretation of quantum theory. Princeton University Press

Everett, Allen and Roman, Thomas (2012). Time travel \& warp drives. University of Chicago Press Farmelo, editor (2002). It must be beautiful: Great equations of modern science. Granta Books Gasperini, Maurizio (2008). The universe before the Big Bang. Springer Verlag Gell-Mann, Murray (1994). The quark \& the jaguar. W.H. Freeman \& Company Ghirardi, Giancarlo (2004). Sneaking a look at God's cards. Princeton University Press Gleiser, Marcelo (2010). A tear at the edge of creation. The Free Press, Simon \& Schuster Gott, Richard (2001). Time travel in Einstein's universe. London. Weidenfeld \& Nicolson Greene, Brian (2004). The fabric of the cosmos. Allen Lane, Penguin Books Greene, Brian (1999). The elegant universe. Jonathan Cape, Random House Greene, Brian (2011). The hidden reality: Parallel universes and the deep laws of the cosmos. New York. Alfred A. Knopf

Gribbin, John (1995). Schrödinger's kittens. Weidenfeld \& Nicolson

Gribbin, John (1992). Unveiling the edge of time. New York. Harmony Books Gribbin, John (2009). In search of the multiverse. Allen Lane, Penguin Books Guth, Alan (1997). The inflationary universe. Jonathan Cape, Random House Halpern, Paul and Wesson, Paul (2006). Brave new universe: Illuminating the darkest secrets of the cosmos. Joseph Henry Press

*Havil, Julian (2012). The irrationals Princeton. University Press

Hawkins, Michael (1997). Hunting down the universe. Helix Books

Highfield, Roger and Coveney, Peter (1990). The arrow of time. Fawcett Columbine Books

Hodgson, David (1991). The mind matters: Consciousness and choice in a quantum world. Clarendon Press, Oxford University Press

Hodgson, David (2012). Rationality + consciousness = free will. Oxford University Press

*Hoffmann, Dirk (2011). Grenzen der Mathematik. Spektrum Akademischer Verlag, Springer Verlag Johnson, Steven (2001). Emergence. Allen Lane

Kaiser, David (2011). How the hippies saved physics: Science, counterculture, and the quantum revival. W. W. Norton \& Company

Kaku, Michio (1994). Hyperspace. Oxford University Press

Kaku, Michio (1995). Beyond Einstein. Anchor Books, Random House

Kaku, Michio (1999). Intro to super strings and M theory, 2nd edition. Springer Verlag

Kumar, Manjit (2009). Quantum: Einstein, Bohr, and the great debate about the nature of reality. Icon Books

Krauss, Lawrence (1991). The fifth essence. Basic Books

Krauss, Lawrence (2005). Hiding in the mirror. Viking Books

Krauss, Lawrence (2012). A Universe from nothing: Why there is something rather than nothing? The Free Press, Simon \& Schuster

Le Poidevin, Robin (2003). Travels in 4 dimensions. Oxford University Press

Le Poidevin, Robin editor (1993). The philosophy of time. Oxford University Press

Lockwood, Michael (1989). Mind, brain and the quantum. London. Basil Blackwell

Mikhail Monastyrsky (1998). Modern mathematics in the light of the Fields medals. Wellesley, MA.

A.K. Peters

Mitch Albom (2013). The time keeper. Hyperion Books

Mook, Delo, \& Vargish, Thomas (1987). Inside relativity. Princeton University Press

Nørretranders, Tor (1993). Mærk verden. Copenhagen. Gyldendal

Novikov, Igor (1998). The river of time. Cambridge University Press

Oerter, Robert (2006). The theory of almost everything. Plume, Penguin Books

O'Shea, Donal (2007). The Poincaré conjecture. Walker \& Company

Overbye, Dennis (1991). Lonely hearts of the cosmos. Harper \& Collins 
Pagels, Heinz (2009). Perfect symmetry: The search for the beginning of time. Simon \& Schuster Palfreman, Jon and Langston, William (1995). The case of the frozen addicts. Pantheon Books Pauli, Wolfgang (1958). Theory of relativity. Dover Publications

Penrose, Roger (1994). Shadows of the mind. Oxford University Press

*Penrose, Roger (2010). Cycles of time: An extraordinary new view of the universe. London. The Bodley Head, Random House

Penrose, Roger et al. (2011). Consciousness and the universe. Cambridge UK. Cosmology Science Publishers

Price, Huw (1996).Time's arrow and Archimedes's point. Oxford University Press

Prigogine, Ilya, and Stengers, Isabelle (1997). The end of certainty: Time, chaos, and the new laws of nature. The Free Press, Simon \& Schuster

Ramachandran, V.S. (2011). The tell-tale brain: A neuroscientist's quest for what makes us human. W.W. Norton \& Company

Randall, Lisa (2005). Warped passages. Allen Lane, Penguin Books

Rees, Martin (2001). Just six numbers. Basic Books

Rees, Martin (1997). Before the beginning. Simon \& Schuster

*Ryder, Lewis (1985). Quantum field theory. Cambridge University Press

Sabbagh, Karl (2002). Dr Riemann's zeros. London. Atlantic Books

* Saunders, Simon (1991). The philosophy of vacuum. Oxford University Press

*Schiff, Leonard (1968). Quantum mechanics. McGraw-Hill

*Wolfram Schommers, editor (1995). Symbols, pictures and quantum reality. Singapore. World Scientific Publishing Company

Siegfried, Tom (2002). Strange matters. Joseph Henry Press

Siegfried, Tom (2000). The bit and the pendulum: From quantum

computing to $M$ theory, the new physics of information. John Wiley \& Sons

Silk, Joseph (2006). The infinite cosmos: Questions from the frontiers of cosmology. Oxford University Press

Silk, Joseph (1980). The Big Bang. W.H. Freeman \& Company

*Silverman, Mark (2008). Quantum superposition: Counterintuitive consequences of coherence, entanglement, and interference. Springer Verlag

Singh, Simon (1997). Fermat's last theorem. Harper \& Collins

Smolin, Lee (2013). Time reborn. Allen Lane, Penguin Books

Smolin, Lee (2000). Three roads to quantum gravity . Weidenfeld \& Nicolson

Stapp, Henry (2007). Mindful universe: Quantum mechanics and the participating observer. Springer Verlag, The Frontiers Collection

Stapp, Henry (1993). Mind, matter and quantum mechanics. Springer Verlag

Steinhardt, Paul and Turok, Neil (2007). Endless universe: Beyond the Big Bang. Doubleday, Random House

Stephen Hawking (1988). A brief history of time. Bantam Dell

*Stevens, Charles (1995). The 6 core theories of modern physics. Cambridge MA. MIT Press

Susan Greenfield (2000). The private life of the brain. John Wiley \& Sons

Tegmark, Max (2014). Our mathematical universe: My quest for the ultimate nature of reality. New York. Alfred A. Knopf

Ulrik Uggerhøj (2005). Tid - den relative virkelighed. Aarhus Universitetsforlag

Vilenkin, Alex (2006). Many worlds in one: The search for other universes. Hill \& Wang, Farrar, Straus, \& Giroux

Walker, Evan Harris (2000). The physics of consciousness. Cambridge, MA. Perseus Publishing Wills, Christopher (1993). The runaway brain. Basic Books

Woit, Peter (2006). Not even wrong. Jonathan Cape, Random House 
Yanofsky, Noson (2013). The outer limits of reason: What science, mathematics, and logic cannot tell us. Cambridge, MA. The MIT Press

Yau, Shing-Tung (2010). The shape of inner space: The universe's hidden dimensions. Basic Books

*Zeh, Dieter (1989). The physical basis of the direction of time. Springer Verlag

*Zeh, Dieter (2012). Physik ohne Realität. Springer Verlag

Zeilinger, Anton (2007). Dance of the photons. C. Bertelsmann Verlag, Farrar Straus \& Giroux 